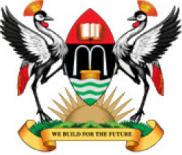

East African School of

Higher Education Studies \& Development
Makerere Journal of Higher Education

ISSN: $1816-6822 ; 3(1)$ (2011) $59-71$

DOI: http://dx.doi.org/10.4314/majohe.v3i1.6

(C) The Author(s) 2011

Reprints \& permission: EASHESD

http://ajol.info/majohe

\title{
Campus Cultism in Nigeria's Higher Education Institutions: Origins, Development and Suggestions for Control
}

\author{
K. O. Fayokun ${ }^{1}$ \\ ${ }^{1}$ Obafemi Awolowo University [E-mail: kfayokun@yahoo.com]
}

\begin{abstract}
This study situates the incidence of campus cultism in Nigerian HEIs in the broader area of higher education student activism. Starting with examination of commonly known forms of student activism, the study contrasts the cults in Nigeria's HEIs with traditional student activist organizations. It notes that the cults are not only unlike traditional student activist organizations but present serious threats for the wellbeing of their members, institutions and society. Thus, it examines the origins and development of the cults to explain why and how they attract and maintain their membership. It concludes that campus cultism is due to social, economic, educational and political grievances, adding that cults attract students because the students have needs that predispose them to affiliate with activist organizations. The study identifies these needs before arguing that, to be effective, efforts to control cultism must address the needs that attract students to the cults.
\end{abstract}

Keywords: Campus cultism; Education management; Legal control

\section{$1 \quad$ Introduction}

According to Sayers \& Altbach (2002) students, as a force on campus and in society, must be understood by all who study or manage institutions of higher education. Authors like Altbach (1997) and Oni (2009) indicate that student activism is one of the important aspects of this (student) force that scholars on higher education and higher education institutions (HEI) managers need to understand. Defining it as heightened political or social activity among students, Sayers \& Altbach (2002) note that the impact of student activism, on campus and in society, can be a force for change-or for disruption. Hence, the need to understand the activism, its motivations, forms, impact and strategies for containing its potential for disruption. It is against this background that this 
study delved into campus cultism - a peculiar and lethal form of student activism in Nigeria's HEIs.

The study situates the incidence of campus cultism in Nigerian HEIs in the broader area of higher education student activism. Starting with examination of commonly known forms of student activism as well as their impact and motivations, the study contrasts the campus cults in Nigeria's HEIs with the more traditional student activist organizations. It notes that the cults are not only unlike the traditional student activist organizations but present serious threats for the wellbeing of their members, campus communities and society at large. Why? To respond to this question, the study poses two questions: when and how did the cults start? 2) Why and how do they attract and maintain their membership?

Subsequently, it traces the origins of the cults to the Pyrates Confraternity, founded by Wole Soyinka (now a Nobel Laureate) and six undergraduates at the University of Ibadan in 1952. It is noted that the group typified the attributes of student activist organizations worldwide. However, by 1972, the group and similar groups had derailed from the attributes of traditional student activism and become obscure and occultist paramilitary organizations that frequently confronted each other and other targets on- and off-campus. The study examines the findings/ views of researchers on the subject of using political economy theory, opportunist theory and subculture theory as frames of analysis. This is with the conclusion that although the methods and activities of the cults are problematic, the phenomenon of campus cultism arises out of social, economic, educational and political inadequacies and grievances at individual and community levels. Thus, the cults' ability to attract students is not surprising. Like higher education students involved in other forms of activism in Nigeria and elsewhere, the followers of these cults have needs and are in circumstances that predispose them to seek membership to activist organizations. The only difference is that, in the case of the cults, the students' needs and circumstances are manipulated and their strength abused to pursue undesirable ends.

Therefore, it is argued that, to be effective, efforts to control the cults' excesses must be grounded on appreciation of the social, economic, educational and political needs that attract students to the cults, so that focus is put on addressing these needs rather than attacking the cults per se as has been done over the years. Recommendations towards realization of this suggestion are made.

\section{Forms and Impact of Student Activism}

Throughout the history of higher education worldwide, students have often been important political actors (Sayers \& Altbach, 2002). These authors add 
that the most visible student organizations and movements are engaged in activist politics although there are many less dramatic student organizations, ranging from cultural and social groups (including fraternities and sororities) to student publications, newspapers, athletic groups and religious organizations. Notwithstanding the variety of forms of student activism, a desire by the activist students to correct campus or society ills and/ or assert alignment with an identity permeates most known forms of activism. Indeed, student activist movements have been the force behind monumental changes in many countries (e.g. Afghanistan, Indonesia, Serbia, South Korea, South Africa and United States). Sayers \& Altbach (2002: 582) note that:

The college or university is a particularly favourable environment for the development of organizations and movements among students. It is an active environment that stresses independent thought and analysis along with intellectual values, theories, and ideals that may call into question established social and political norms. University faculty, through their teaching and research, may also provide an atmosphere that legitimates dissent, or at least stimulates discussion about social and political issues...It is commonly recognized that such activities are an important part of the higher education experience and that the academic culture of the college or university extends beyond the classroom. The academic culture of the university also provides a considerable amount of free time for students to engage in extracurricular activities. Universities are in most instances "age-graded" cultures, where the majority of students are of a similar age and at a stage in life when they seek a sense of community and belonging. Also, with the daily lives of students centred around a physical campus, communication among students takes place naturally.

\section{Difference between Traditional Student Activism and Cultism in Nigerian HEIs}

In Nigeria, a significant proportion of student activism does not present a desire by the activist students to correct campus or society ills and/ or assert alignment with an identity. Rather, it has been abused to form cults-covert activist cum religious occultist associations that are not only dangerous to themselves but to others who are on the campus to pursue their legitimate goals (Oni, 2009). The cults mostly operate underground, bestriding the campus landscape like a colossus whenever they choose to strike.

Surreptitiously hiding their identity from other members of the university community, members of the campus cults are bold, daring and deadly. Their activities involve murder, rape and robbery, among other forms of violent 
crime. Their violence is usually characterized by the use of arms such as guns, axes, machetes, knives and broken bottles so it has led to varying degrees of homicide, maiming and sorrow. For example, in the wee hours of Saturday July 10, 1999, a gang of cultists invaded the Obafemi Awolowo University campus in the south-western part of Nigeria and unleashed terror on the institution in a deadly violent attack. The gang's ruthlessness was mostly felt in two of its male hostels where five undergraduates were brutally hacked to death in cold blood. Using the cover of darkness at a time when most students were deep in their sleep after a night of busy campus-life activities, the gang struck. Armed with guns and parading both male and female members, the deadly gang descended on the hapless students in a commando-style operation which lasted some few minutes before the attackers disappeared in thin air through a nearby bush. By the time the smoke cleared, many casualties littered the scene of the incident, the victims including prominent members of the Students' Union body.

\section{$4 \quad$ Problem and Knowledge Gap}

The problem is that the prevalence of campus cults in Nigeria's higher institutions has engendered a culture of violence with its attendant consequences for the development of HEIs and society at large. The heightened tempo of cult activities in HEIs has its negative impact on learning as cult violence is often associated with the truncating of school calendars, disruption of programmes, suspension of term activities, withdrawal of students, general breakdown of law and order and wastage of resources. A seeming tranquillity in an institution can suddenly be terminated by an invasion by members of a cult, resulting into violence, destruction of infrastructure, disruption of activities, maiming and death (cf. Adawo, 2010). It is estimated that, between 1996 and 2003, over one hundred and eighty (180) students were killed in violent gang warfare as a result of the activities of campus cults (Okebukola, 2003). A lot of property was also destroyed during the same period.

The menace of campus cults has posed challenges for the managers of HEIs in Nigeria that a multiplicity of authors (e.g. Adeola, 1997; Babarinde, 1998; Daminabo, 1991; Freedom Watch, 1997; Fayokun, 2003; Ossai, 2001) indicate that no aspect of Nigeria's education system has troubled the national conscience as the manifestation of secret cults in HEIs. Several summits, conferences, talk-shows and seminars have been held on campus cultism and the challenges they pose to higher education in Nigeria. Numerous academic papers had been presented, many of them offering "water-tight and elegant plans of action" to contain the "hydra-headed monster". All agree that confronting campus cultism is a difficult task fraught with many problems and 
conflicts. In 1997, the Federal Government of Nigeria constituted a team to discuss the menace of secret cults in HEIs. The team came up with recommendations for stamping out the cults but no significant achievements were made against the cults. In 1999, the federal government directed University Vice-Chancellors to eradicate cults from their campuses or lose their jobs but this too did not result into elimination of the cults. Hence the questions: 1) When and how did campus cultism in Nigeria start? 2) Why and how do campus cults attract and maintain their membership? 3) Does the history and nature of campus cults point to any suggestions for controlling them? Using related literature, this study attempts to respond to these questions.

\section{Development of Campus Cultism in Nigerian HEIs}

Abdu (2003), Ekong (2003) and Onoyase et al. (2008) trace the emergence of campus cults in Nigeria to the Pyrates Confraternity, founded by Wole Soyinka (now a Nobel Laureate) and six undergraduates at the University of Ibadan in 1952. At its inception, the Pyrates Confraternity, far from advocating a culture of violence, had as its aims noble ideals like the ending of tribalism, elitism, neo-colonialism and promotion of chivalry. For some years the Pyrates Confraternity required Spartan qualities in its membership and was the only student club of its kind. Its activities were devoid of violence and its members were held in high esteem among the student populace. It held public meetings, kept a directory of its membership and published a campus paper entitled Scorpion. Clearly, the group typified the attributes of higher education student activist groups (cf. section 2).

However, later, the Pyrates Confraternity derailed from its founding mission as an ideological activist group and became a secret cult. In 1972, a prominent member of the group, who fell afoul of the group's norms, was expelled for indiscipline. In protest, he pioneered a splinter group known as the Buccaneers. As time went by, other breakaway factions emerged, many of them motivated by rancour, feud and personal rivalry. A group known as Eiye was formed out of the bigger faction and it became a ready haven for many who failed in their bid to join the older groups. These groups rivalled against each other and kept watchful eyes not only on their members but also the activities of their rivals.

Many of the students denied admission to or expelled from a group harboured feelings of bitterness, envy and vengeance against the group. Thus, they sought opportunities for revenge. These students started new cults, not for the ideals that student activist organizations traditionally stand for but vengeance against rival groups. In due course, the violence used in confronting rival cults was deployed to any grievance that the leadership of the cults 
deemed required a violent response. These developments invariably degenerated into open skirmishes, confrontation and violent clashes. Mostly non-pulsed by the ensuing violent clashes, the response of University managers was usually a hurried closure of the institutions and a proscription of student groups without making a thorough study of the malaise of campus cultism. Of course, this "fire brigade" approach often proved to be merely cosmetic as the groups were merely driven underground where their activities found a festering ground to thrive and become more intricate. The next phase in the growth of campus cults involved the spread of the cults from the HEIs where they had started to neighbouring campuses where they launched massive recruitment drives in a cutthroat-like competitive manner. The resilience of campus cults could be seen in their enduring of most unfavourable conditions and environment. Where the atmosphere became too hostile to their recruitment and organization, they relocated to more conducive neighbourhoods but did not give up their activities. Today, cults can be found in all HEIs in the country. They have also spread to many high schools.

\section{Types and Activities of Campus Cults in Nigerian HEIs}

Abdu (2003) has listed as many as eighty five cult groups operating in Nigeria's HEIs. No campus is known to be spared of their activities. The most prominent of these cults are classified into five categories as follows: Classical fraternities; God-father secret cults; Female cults; Mafia cults; and Terrorist cults. Though each of the cults claims a distinct identity and operates within its own belief system, they are all prone to violence and are characterized by brainwashing of neophytes, close mindedness of members, assumption of a distinguishable identity, covenant-induced brotherhood and intolerance of others outside their belief system.

The members of each cult are very strong-willed, close-minded, and operate under a command structure. As a result, they are found to go to any length to achieve their objectives or preserve their secrets. Due to their intolerance, they expend considerable energy denouncing other groups. In general, they are not receptive to rational ideas or thinking. Rather, they hold isolated or radical views. Their activities are usually pronounced during recruitment drives, initiation periods, social and political functions on campus or whenever there is a score to settle with opponents. Initiation into the cults is usually done at night in obscure places like dense jungles, cemeteries, abandoned buildings, lockedup classrooms or market stores. There is a thick air of secrecy around cult groups and their activities, which they mostly conduct in the night. Members of cult groups are bound under an oath of secrecy not to divulge information on 
the identity of other members or the group's activities. Initiation rites are usually frightful scenes where new members are made to enter into blood covenants to seal their commitments to the group and its objectives (Oni, 2009).

Cults promise their members who feel threatened by perceived enemies on the campus security. They help their members to gain power and influence (e.g. in the leadership of student guilds). They also promise to help their members to achieve desired grades in examinations. Some cults promise to satisfy their members' personal needs (e.g. money, food, drinks, drugs, clothes, cars, weapons, etc.) The cults provide mercenary services for people who need to attack or intimidate opponents (e.g. unscrupulous politicians who resort to the use of malice and violence to outwit their opponents). Cults terrorize campus communities and their neighbourhoods, to make them ungovernable and frustrate leaders that are hostile to their activities. Some of the campus cults affiliate with cults in the wider Nigerian community and recruit students for the cults in the larger community. Using their network of past and present members, they secure employment some of their members upon graduation. They also link their members to an influential political and professional network, including police officers, army officers, tax people, lawyers and officers of the judicial service among others. The cults also run sex and drug trade rings.

\section{Why and how do the Cults Attract and Keep their Followers?}

Many reasons have been advanced for the emergence and proliferation of campus cults in Nigeria's HEIs. Sociologists have advanced three theories on the causes of cultism in the society, namely, political economy theory; opportunist theory; and subculture theory. The political economy theory postulates that inequality in the society breeds vices like corruption, violent crimes, robbery, gangsters and cultism. On the other hand, opportunist theory states that there are prevailing societal conditions which predispose the people of the society to manifest certain characteristics and behaviour. Finally, subculture theory explains that whenever a subculture (in this case cultism) is allowed to develop, eradicating it becomes extremely difficult Abdu (2003).

In concurrence, related literature (e.g. Kazi, 1999; Oni, 2005; Ekong, 2003) suggests that the emergence of violent cult activities coincided with the militarization of the national polity. Gross mismanagement of public funds, dwindling economic fortunes, inadequate funding of education, mass importation of arms, influx of alien cultures into the Nigerian society, proliferation of hard drugs, exposure of students to occultism literature and violent films (whose characters serve as role models for the youths), moral 
decadence and corruption in the society have also been cited as all precipitating factors (see, for example, Oni, 2009; Adeola, 1997; Fayokun, 2003; Ikudayisi, 1998; Marcel, 1997; Smah, 2001). The violent nature of campus cults became noticeable from the early 1980s when corruption, mismanagement and nepotism began to take their toll on the Nigerian psyche. At the same time, a crop of leftist radicals in the citadels of learning assumed the role of a formidable opposition to the elite ruling class and military junta. In an attempt to crush these opponents, the military instigated and equipped cult groups to destabilize the ranks of critics. Within the university system itself cult gangs became ready tools for oppression and repression. The idea of "god-fatherism" took root, whereby cult groups provided the needed appendage to campus power brokers. It is believed that some managers of HEIs used cult groups to counter student activism for reforms in the management of their institutions. Even among the rank and file of university staff, cult groups were used to settle scores or silence perceived enemies.

Other factors given for the attractiveness of campus cults to youths include collapse of the family structure and good parental training; peer influence; a search for answers to felt needs (emotional, academic, financial etc); need for belongingness; inquisitiveness; lack of rigorous academic challenges or failure to measure up to these challenges in instances where they exist (i.e. substitution of efforts to succeed academically with participation in cult activities); and despair (for instance due to poverty and unemployment). It is noteworthy that in separate studies relating students' campus cult involvement and social adjustment, Oni (2009), Nwogu (1997) and Thompson (1998) concur that these factors indeed explain the proliferation of campus cults and their ability to attract and maintain followers. According to Nwogu (1997), for instance, cult members experience a high degree of social maladjustment because they have great difficulty in incorporating the values and standards of the society. Oni (2009) and Nwogu (1997) are corroborated by Faliye (2003) who observes reports members of campus cults harbour deep feelings of rejection, worry and dissatisfaction that cause the emotional outbursts and poor impulse control that predispose them to acts of rape, murder and assault among other antisocial behaviours. It may also be noted that these factors are highly similar to those that have been identified for student activism (cf. 2). Here, the inference is that although the activities of the campus cults are detrimental and undesirable, it is not difficult for them to attract and keep followers. Like higher education students involved in other forms of activism in Nigeria and elsewhere, the followers of these cults have needs and are in circumstances that predispose them to seek membership to activist organizations. The only difference is that, in the case of the cults, the students' needs and circumstances are manipulated and the strength arising out of the students' collective activity abused to pursue undesirable ends (Onoyase et al., 2008). 


\section{Implications for Control of Campus Cultism}

The first, and most important, implication of the foregoing discussion is that efforts to control the cults' excesses must be grounded on appreciation of the fact that, like higher education students involved in other forms of activism in Nigeria and elsewhere, the followers of campus cults have needs and are in circumstances that predispose them to seek membership to activist organizations. Thus, these efforts should focus on addressing these needs rather than attacking the cults per se as has been done over the years. In particular, there is need to promote the development of student activist organizations that will address the students' needs for identity and collective bargaining albeit without recourse to the excesses associated with the cults. Oni (2009:270) writes in concurrence:

...there is a need for a helping relationship that will enable students cope with the many problems of campus life...the cultists themselves need help to be able to understand themselves better and consequently live within the accepted values of the society.

Once avenues for gratifying the students' needs have been established to provide an option for potential cultists, government should put in place policy measures for stamping out cultism on our campuses. This includes the enactment of a comprehensive legislation to tackle the malaise of cultism in our society. Strongly worded legislation should equate cultism in the universities with cultism in the general society to be criminalized and penalized seriously. Secondly, an intelligence network should be expanded to apprehend cultists who are terrorizing the campuses. Security measures should be beefed up on the campuses with the police supporting the security outfits of the institutions in their operations. Each of the campuses should launch efficient machinery for weeding out known cultists and their intelligence units should be empowered and equipped to deal decisively with cult members. Water-tight security measures on campuses should be extended to the immediate communities where the campuses are located. There is the need of appointing only competent, courageous, honest, principled and uncompromising judicial personnel to preside over cult-related cases. Investigation of cult-related violence should be thorough and adequate protection provided for investigators, prospective witnesses and judicial officers. Committed cultists should be penalized without fear or favour and their identities properly publicized to attract public condemnation and serve as deterrence for prospective cult members. It may be noted that several authors (e.g. Ede, 1995; Ige, 2000) recommend equally tough responses to the problem of student cultists.

Nevertheless, it must be recognized that by themselves, legislation on cultism and prosecution of cultists can achieve very little. One effective 
measure for controlling the spread of campus cults is the instilling of the fear of God in our young minds at their earlier ages. We need to inculcate and promote proper parenting. No one can underestimate parental role in the shaping of the character of their children. The fear of God must be effectively instilled in pupils in lower schools. Students entering high schools should be properly instructed in moral and religious education. Moral instruction should be carried on through different methodologies even at the tertiary level. Religious leaders were found to be effective in helping university administrators to deal with campus cultism in the past. The drumbeats of moral renaissance which followed the bloodbath and cult violence at Obafemi Awolowo University IleIfe in 1999 led to many cultists renouncing their membership of cult groups in the public glare. This underscores the fact that efforts aimed at catching the youths at their earlier ages were not in vain. Thus, it is expedient to start creating awareness of the negative influence of cult groups among pupils right from the primary schools. Having a virile Guidance and Counselling unit in the Students Affairs Division of the university that will invigorate anti-cultism ideas in students on campuses is imperative. This suggestion is in concurrence with the conclusion of Oni (2009: 272) that:

Religious organizations, counsellors, students, parents and guardians should see themselves as part of the effort to save our tertiary institutions. Without our joint efforts in this regard, decrees and instruments of terror will achieve nothing.

In concurrence, Alemika (2000) concluded that the only way to eradicate cultism from our HEIs is by using spiritual leaders to organise noncongregational services and counselling in schools. This multifaceted effort that integrates the input of all the stakeholders in higher education is supported by other researchers (e.g. Omotosho et al., 2008; Onoyase et al., 2008). For example, Onoyase et al. (2008) conclude that:

...the use of coercion, persuasion, public awareness campaign, public renunciation and school disciplinary measure have been found effective in the management of cultism (Onoyase et al., 2008: 213).

Regulating activities in the university communities will go a long way in tightening the lax security in and around the campuses. All groups and associations within university campuses should be properly screened before their registration. Likewise all groups and associations outside the campuses to which student groups are afflicted should be screened to examine the level of their influence on students. The universities and the government should address the issue of illegal possession of arms and ammunition as well as the phenomenon of drug abuse among students. Students should sign bonds against cultism on admission (Oluwatobi \& Babatunde, 2010). This should be complemented with a good monitoring system of their activities during college sessions. More particularly, setting up of vigilance groups against campus cults 
by the generality of the students themselves has been found to be a good control measure against campus cultism.

Stepping up rigorous scholarships in the institutions will keep the students busy with their studies and leave them with little time for frivolity. Positive relationships have been hypothesized between the amount of busy time students have on campuses and their non-involvement in cult activities (Okebukola, 2003). This suggestion derives credence from Adawo (2010) who contends that:

[the] leading problem in cultism is admitting non-academic students into the university. And because they do not belong to academics, they sit back to practice what they belong [sic]. This is a spill-over effect of examination malpractice through which they found admission into universities.

For instance, Medical students have been found to be the busiest on campus and their level of participation in cult activities is recorded to be the lowest. In concurrence, Sayers \& Altbach (2002) report that, in the United States, HEIs control the extent of student action using course load. When the universities were well funded and lecturers were well remunerated, there was no instability in the academic calendar and no dull academic moment for students. Schools terms were filled with academic activities, field trips, tests, etc., leaving little room for non-academic activities. Writing in concurrence, Oni (2009) recommends that teaching aids and research materials should be made available to the teachers.

\section{References}

Abdu, P. S. (2003). Campus cultism in Nigeria's tertiary institutions: a general overview. Education Today. Abuja: Federal Ministry of Education.

Adawo, M. A. (2010). Non-quantifiable variables and their influence on Nigeria's education (mostly university education) and economic growth in Nigeria. Journal of Economic Theory 4(1), 25-30.

Adeola, I. O. (1997). Secret cults in Nigerian institutions of learning: as periscopal appraisal. In: Ogunnameru, O. A. (Ed.) Readings on campus secret cults, pp. 51-69. Ile-Ife: Kuntel Publishing House.

Alemika, E. E .O. (2000). Management of Students Unions and anti-cult Unions and anti-cult mobilization in Nigeria tertiary academic institutions. Paper presented at the workshop on security issues in the eradication of cultism in tertiary institution. Abuja.

Altbach, P. G. (1997). Student politics in America: a historical analysis. New Jersey: Transaction Publishers. 
Babarinde, K. (1998). Cultism, campus violence and students developmental process in Nigeria. In: Jiti $\mathrm{O}$. et al. (Eds.) Nigerian students and the challenge of leadership, pp. 36-48. Lagos: CDHR Publications.

Daminabo, M. (1991, May 7). Campus cults and student unionism. The Guardian, p. 9.

Ede, S. N. (1995). University management in Nigeria: key issues. Jos: Source Publishers.

Ekong, G. (2003). Cultism: the hydra-headed monster. Education Today. Abuja: Federal Ministry of Education.

Faliye, Z. M. (2003). Cultism in institutions of higher learning in Nigeria. Education Today. Abuja: Federal Ministry of Education.

Fayokun, K. O. (2003). Cultism in education institutions. Education Today. Abuja: Federal Ministry of Education.

Freedom Watch (1997). The menace of secret cults on campuses. CDHR Monthly: July edition.

Ige, B. (2000). Death penalty for student cultists. The Punch Wednesday June 28, Vol. 17, No 7904 pp. 1- 2.

Ikudayisi, T. O. (1998). Cultism as an agent of violence: the challenges of the $21^{\text {st }}$ century. In: Adegboye, A. Oluwatimilehin, J. T. B., Ogungbemi, E. O., Ogunribido, R. O., Olotu, D. (Eds.) Cultism in Nigerian institutions of learning, pp. 88-99. Ikere: Ondo State College of Education.

Kazi, N. P. (1999). The student factor in crisis in Nigerian Education: the way out. Journal of Educational Studies 5(1), 10-19.

Marcel, J. (1997). Behind the secret cults. Today's psychology 1(2), 27-30.

Nwogu, A. (1997). Personality profile of thirteen secret cult members. Today's psychology 1(2), 20-22.

Okebukola, P. (2003). Control And Eradication Of Secret Cults In Higher Institutions In Nigeria. Education Today. Abuja: Federal Ministry of Education.

Oluwatobi, P., Babatunde, V. (2010). Cultism or gangsterism and its effect on moral development of learners in Nigerian tertiary institutions. Journal of Emerging Trends in Educational Research and Policy Studies 1(2), 61-64.

Omotosho, J. A., Esere, M. O., Aina, J. S., Omotosho, F. A. (2008). The Role of Tertiary Education Stakeholders in Stemming the Tide of Cultism on University Campuses in Nigeria. Nigerian Journal of Guidance and Counselling 13(1), 13-24.

Oni, A. A. (2005). A causal model of some perceived socio-psychological and academic factors as determinants of cult membership among university students in South-West Nigeria. Unpublished PhD thesis: University of Ibadan. 
Oni, A. A. (2009). Citadel of violence: effect and control of cult activities on students' social adjustment in Nigeria. African Journal of Crime and Criminal Justice 1(1), 257-275.

Onoyase, D., Onoyase, A., Arubayi, D. (2008). Effective Cultism Management Techniques as Perceived by Staff and Students in Higher Education: A Case Study of Federal Colleges of Education in Nigeria. Journal of Social Science 16(3), 209-214.

Ossai, A.G. (2001). Cultism and the management of higher education. Seminar paper presented at the faculty of Education. Abraka: Delta State University.

Sayers, K. W., Altbach, P. G. (2002). Student activism. In Forest J. J., Kinser K. (2002). Higher education in the United States: an encyclopaedia (Volume 2, $M$-Z). California: ABC-CLIO.

Smah, S. O. (2001). Perception and Control of Secret Cult and Gang-induced Difficulties for Quality Living and Learning in Nigerian Universities: The Case study of Universities in the Middle Belt Zone. Jos: Centre for Development Studies, University of Jos, Nigeria.

Thompson, S.A. 1998, Introduction to Cultism. London: Routledge and Regan Paul Ltd. 